\title{
Compensation of Unusual Working Schedules
}

\section{Juliane Scheffel*}

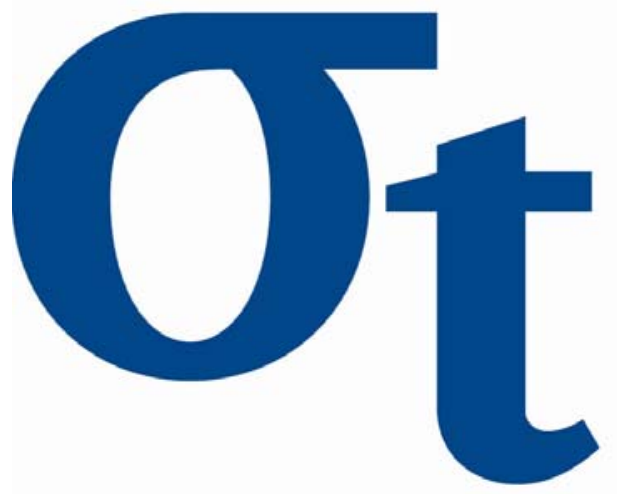

* Humboldt-Universität zu Berlin, Germany

This research was supported by the Deutsche Forschungsgemeinschaft through the SFB 649 "Economic Risk". 


\title{
Compensation of Unusual Working Schedules
}

\author{
Juliane Scheffel ${ }^{*}$ \\ Humboldt Universität zu Berlin
}

18th May 2011

\begin{abstract}
This paper examines pecuniary aspects of work during unusual hours based on the German Time Use Data for 2001/02. The findings show positive wage premia of $9-10$ percent for shift workers and men who work during unusual hours. There is some evidence of negative selection which suggests that men with lower potential daytime earnings have a higher propensity to choose these jobs because of the associated wage premium. The findings further show a U-shaped impact of temporal work disamenity across the wage distribution with higher wage premia paid to the extreme 5-percentiles.
\end{abstract}

Keywords: Shift Work, Non-Standard Working Hours, Time Allocation, Compensating Wage Differentials, Wage Premia, Quantile Regression

JEL Classification: J22, J31, J33, J81

\footnotetext{
* Presented at the Annual Conference of the European Society for Population Economics in Essen, June 09 - 12, 2009, the Annual Congress of the European Economic Association in Glasgow, August 23 - 26 and the Annual Conference of the Royal Economic Society in London, April 18 - 20. I thank Jan Peter Aus dem Moore, Florian C. Buck, Michael C. Burda, Hanna Denecke, Erik Fasten, Alexandra Fedorets, Daniel S. Hamermesh, Astrid Kunze, Michael Kvasnicka, Dorothee Schneider, Battista Severgnini and Alexandra Spitz-Oener for helpful comments. This research was supported by the Collaborative Research Center 649 of the German Science Foundation (Deutsche Forschungsgemeinschaft). All errors are mine. Institute for Economic Theory II, School of Business and Economics, HumboldtUniversität zu Berlin, Spandauer Str. 1, 10099 Berlin, Germany, scheffel@wiwi.hu-berlin.de
} 


\section{Introduction}

In Germany, the share of shift workers steadily rose from 11 percent in the early 1990s to about 17 percent in 2008. A relaxation of regulations such as the shop opening hours further widen the working time distribution for a day so that work during unusual hours disseminates. Nowadays, shift work and also work during non-standard hours are fundamental work patterns across the German workforce and consequently influence the lifestyle of a large part of the population. These working schedules, however, disrupt the circadian cycle which might adversely affect well-being and increase the risk to health 1

Labor economists generally believe that disamenities must be compensated by higher wages (Smith, 1776: Rosen, 1987). The strong interest of medical and social sciences in the consequences of irregular working schedules shows that such working conditions can be perceived as disamenities which workers try to avoid if possible $\left.\right|^{2}$ In addition, such jobs are found to increase the risks of gastric ulcer (Tüchsen et al. 1994), cardiovascular diseases (Bøggild and Knutsson, 1999) and even of cancer (Davis and Mirick, 2006). The major objective of this paper is to examine the compensation of shift work as well as of unusual working schedules (McNabb, 1989) based on the German Time Use Data for 2001/02.

Although classical labor economic theory predicts substantial wage differentials for non-standard working schedules, in particular if health is at risk, there is only little empirical support. Work at non-standard hours is a common disamenity that is not based on individual characteristics and can thus be viewed as objective measure of the burden of work to everybody (Hamermesh, 1996). Only few studies attempt to estimate the size of the resulting wage premium. Kostiuk (1990) was one of the first authors to directly estimate wage premia for shift work in the US but limits his study to male manufacturing workers. He finds a positive selection into daytime work, yet is not able to identify a selection of any kind into shift work. Based on this work and by using better data, Lanfranchi et al. (2001, 2002) find a negative selection into shift work for France. Schumacher and Hirsch (1997) examine wage differentials only for registered nurses and find that shift work accounts for about 10 percent of the premium paid to hospital employees.

The incidence of evening and night shifts declined in Germany over the last decades. The majority of shift work nowadays is rather provided in rotating teams. In contrast, the occurrence of work

\footnotetext{
${ }^{1}$ The circadian cycle represents the regular recurrence of e.g. biological activities in cycles of approximately 24 hours from one stated point to another. See for example Culpepper 2010; ; Minors et al. (1986).

${ }^{2}$ See Presser 1988 1995); Mellor (1986); Shiells (1987); White and Keith 1990;; Mayshar and Halevy (1997) for social science research and Minors et al. (1986); Cunningham (1989); Costa (1996) 2003); Folkard and Tucker (2003) for medical research. Kostiuk (1990); Hamermesh (1999a) are representatives of the few economists addressing this question.
} 
during non-standard hours gained more importance by hence widening the working hours distribution. The rationale behind it is the stronger international integration of product markets and thus the intensification of world demand that requires employers for example to extend the operating hours of machines. If, however, the greater supply of work at unusual hours allows workers to choose these jobs because they prefer these working schedules, wage premia would be generally lower. In this case, no additional pecuniary incentives need to be paid to attract workers to such jobs. In this paper, I estimate the magnitude of wage differentials for two groups of workers with non-standard hours which are shift workers and men who work during unusual schedules in Germany by accounting for sample selection.

I find some evidence for a negative selection which is significant however only for shift workers yet not for men who work during unusual hours. It suggests that workers with more unfavorable characteristics choose such jobs to supplement their earnings as they would earn significantly lower wages for daytime work. The estimated positive and sizeable wage premia imply that workers would rather avoid these jobs but accept them because of the wage differential. I find further evidence of decreasing wage differentials for men with very long working hours which is evidence that non-pecuniary aspects of such jobs outweigh the financial compensation. To better understand the size of wage premia for these jobs across the overall wage distribution, I analyze wage differentials by quantiles and find a U-shaped impact across the earnings distribution. Following Lanfranchi et al. (2001, 2002), I additionally test for poolability of the separate wage equations for different groups to examine whether a treatment effect model or switching regression models with endogenous switching are more appropriate in this context. Poolability is however rejected for all groups of workers.

The paper is organized as follows: the subsequent section presents the theoretical motivation of the subsequent empirical analysis and section 3 gives a description of the estimation strategy. Section 4 is devoted to a description of the data. Additionally, the relevant variables and sample properties are described in more detail as well as the distribution of market work across a standard work day. Moreover, the presentation of the empirical results is divided into two parts: in section 5.1 the determinants of the choice of different types of temporal work disamenity are explored which are important for understanding the underlying selection process on observables. Based on these findings, the wage premia are investigated by accounting for a potential selection of the sample. Finally, section 6 concludes. 


\section{Theoretical Background}

A simple theoretical framework will be presented here which will serve as foundation for the subsequent empirical analysis. Following Hamermesh (1999a), I assume heterogeneous firms. The production technology of the $i$ th firm is given by

$$
\Pi_{i}=\Pi_{i}\left(W_{i}, S_{i}\right)
$$

where $W_{i}$ denotes the hourly wage rate of firm $i$ and $S_{i}$ is an indicator of work during unusual hours.

Each worker $j$ maximizes his utilities given by:

$$
U_{j}=U_{j}\left(W_{j}, S_{j}\right)
$$

where $W_{j}$ is the hourly wage rate earned by the worker and $S_{j}$ is again an indicator for works during unusual hours. The individual's decision about the number of hours worked will not be regarded in this paper as the sample is restricted to full-time employed workers only.

Workers sort themselves among employers depending on their tastes for working schedules and the employer's ability to reduce the incidence of work during unusual hours (Hamermesh, 1990). The firm's isoprofit curves $(\pi)$ are concave and downward sloping because the reduction of work during unusual hours is costly. In contrast, indifference curves $(I)$ of the workers are convex and upward sloping reflecting the higher compensations paid as incentive for work at non-standard working hours. It follows that the locus of all realized market wages (denoted by $W$ ) is a result of the decisions of both, firms and workers in equilibrium and is also upward sloping as shown in the left panel of figure 1 . The wage-disamenity locus shown in this graph illustrates equilibrium combinations for homogeneous workers.

The size of the wage premium paid as incentive for workers to accept jobs which offer unusual working hours $\left(S_{j}\right)$ heavily depends on the distribution of underlying tastes. A fraction of workers might not consider work during more undesirable hours as disamenity so that compensation needs not be very high. Others, in contrast, would only accept work under such conditions, if wages are high enough to compensate for the foregone leisure time which could be spent with sociable companions (Jenkins and Osberg 2005). The distribution of the underlying tastes of the workers hence determines the size of the average wage premium and therefore the slope of the wage locus. 
Figure 1: The Wage-Disamenity Locus.
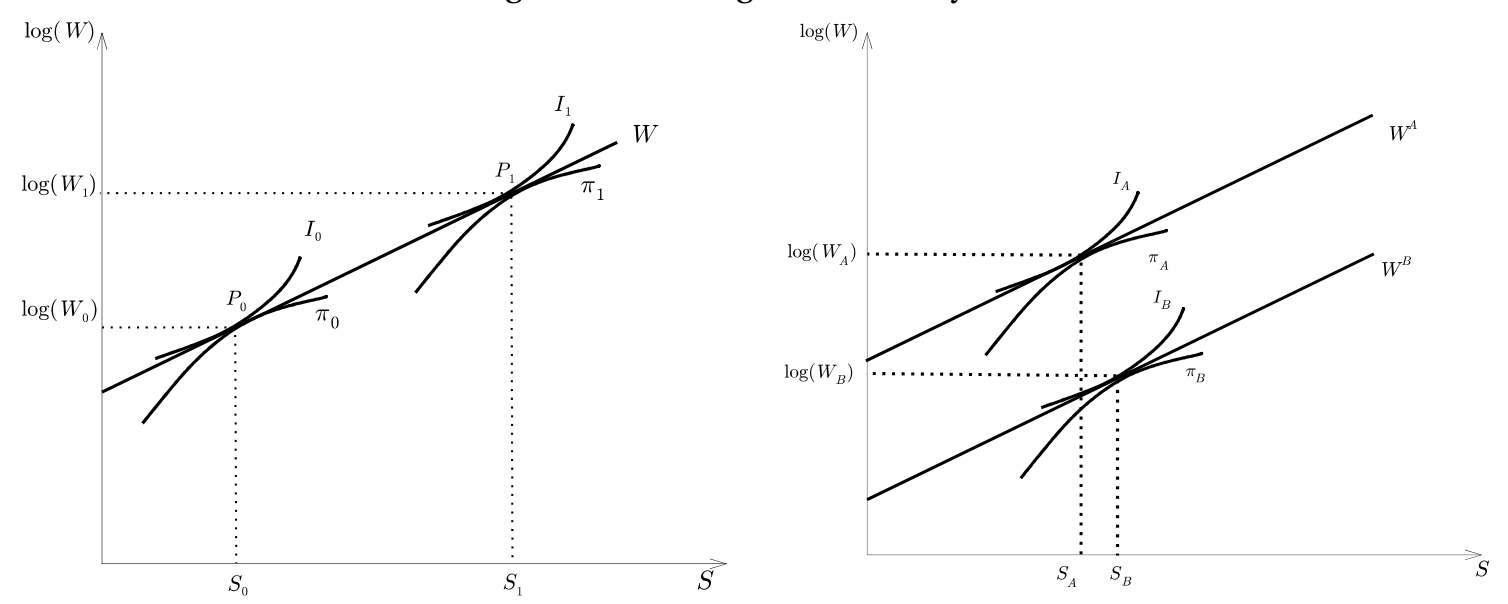

The assumption of heterogeneous workers is further depicted in the right panel of figure 1 . For simplicity, two different types are assumed: A denotes a high-skilled type of worker and B the lowskill type Hamermesh, 1999a. Both market wage-disamenity-loci $\left(W^{A}\right.$ and $\left.W^{B}\right)$ that are realized in equilibrium are shown. It is further assumed for simplicity that both types of workers face the same trade-off between the degree of unusual working hours $(S)$ and log hourly wages which is why both wage loci have the same slope. However, both workers differ with respect to observable skills and are hence remunerated differently. The difference in the intercept of both wage-loci can be interpreted as income effect. Consequently, even without working unusual hours at all, worker A would receive higher wages than workers B. In addition, the figure shows that worker A could use some of his earnings power to avoid work during undesired hours and can therefore reduce $S$ in equilibrium $\left(S_{A}<S_{B}\right)$.

The focus of this study is the determination of the average wage differential for work at nonstandard hours rather than to find the exact slope of the wage loci for different types of workers ${ }^{3}$ For an unbiased as possible determination of wage premia given the limitations of the dataset, it is crucial to account for a potential non-random selection.

\section{Estimation Strategy}

To estimate the influence of the temporal work disamenity on wages, the following simple wage equation will be estimated in a first step:

$$
\ln w=\mathbf{X} \beta+\delta S+\epsilon,
$$

\footnotetext{
3 Hamermesh 1999a and Duncan and Holmlund 1983) amongst others try to identify the slope of the wagedisamenity trade-off.
} 
with $\ln w$ denoting $\log$ hourly wages. The set of control variables can be grouped into matrices of predetermined individual characteristics $(\mathbf{X})$. Furthermore, $S$ is a dummy denoting work during unusual schedules. The error term is denoted by $\epsilon$.

If the choice to work during unusual hours is not entirely random and reflects tastes of a rather selected group of workers, result obtained by simple OLS will be biased. Suppose that the choice of jobs that offer some sort of temporal disamenity is determined according to the following reducedform choice equation:

$$
S^{*}=\gamma \mathbf{Y}+v,
$$

where $S^{*}$ is a latent variable yet only the final binary decision $(S)$ to work in such a job or not is observed. $\mathbf{Y}$ is a matrix of those variables that influence the choice and $v$ is a random error term. The equation further suggests that people choose to work in such jobs if the realized average wage premium exceeds the measured and unmeasured costs of such jobs (Kostiuk. 1990).

The structural wage equations for both groups can be formulated as follows:

$$
\begin{aligned}
& \ln w_{s}=\mathbf{X} \beta^{s}+\epsilon_{s}, \\
& \ln w_{d}=\mathbf{X} \beta^{d}+\epsilon_{d} .
\end{aligned}
$$

In the first equation $\log w_{s}$ denotes $\log$ hourly wages of men with unusual schedules and $\log w_{d}$ refers to the reference group.

To start with, equations (3) and (4) will be estimated by a treatment effects model which is a restricted version of a selectivity controlled wage equation (Lanfranchi et al. 2001). The model assumes that jobs only differ with respect to the working schedules but do not require any additional skills. Put differently, all characteristics are equally valued independent of the timing of work. Consequently, coefficients are constraint to be the same for all men independently of whether they work during non-standard hours or not and a single equation including an indicator variable is appropriate. I will test this assumption in section 5.2 .

To allow for the possibility of different remunerations of skills for the respective groups, I will additionally estimate a switching regression model with endogenous switching. Lanfranchi et al. (2001) show that this is the appropriate model in the presence of non-random selection. If the ability of workers is not captured by the exogenous variables in the choice equation, wages might be affected and the error terms $\epsilon_{s}$ and $\epsilon_{d}$ are biased with non-zero means. If in turn, wages affect 
the choice to work during unusual hours in addition to the influences already captured by the explanatory variables, also the error term $v$ of the choice equation is biased. The direction of this bias depends on the underlying selection process. Given the reduced form choice equation (4) and following Maddala (1983), conditional wages can be computed as:

$$
\begin{aligned}
& E\left(\ln w_{s} \mid S=1\right)=\mathbf{X} \beta^{s}+\sigma_{\epsilon_{s} v} \frac{\phi(\gamma \mathbf{Y})}{\Phi(\gamma \mathbf{Y})} \\
& E\left(\ln w_{d} \mid S=0\right)=\mathbf{X} \beta^{d}-\sigma_{\epsilon_{s} v} \frac{\phi(\gamma \mathbf{Y})}{1-\Phi(\gamma \mathbf{Y})}
\end{aligned}
$$

with $\phi(\gamma \mathbf{Y})$ denoting the normal density function and $\Phi(\gamma \mathbf{Y})$ the normal distribution function of the choice equation. The last term of equations (7) and (8) will account for selectivity.

Results obtained from less restrictive switching regression models which allow for different coefficient estimates for the two groups will be expected to be lower than those from treatment effect models (Kostiuk, 1990). In the case of France, Lanfranchi et al. (2001) reject the hypothesis of poolability of the wage regressions for shift workers. The estimated wage differentials based on the treatment effects model are hence rather an upper limit of the true wage premium.

\section{Data and Descriptive Statistics}

This paper is based on German Time Use Data (Zeitbudgeterhebung) for the year 2001/02 collected by the German Federal Statistical Office (Statistisches Bundesamt 2003). The data set is interesting for the present study as it provides - apart from the usual socio-economic, work and household characteristics - detailed information about the timing of activities for each 10 minute time interval during a day. The analysis of this paper is restricted to full-time employed men aged between 25 and 59 in dependent employment.

Following Burda et al. (2007), the more than 200 reported daily activities are aggregated into four major categories: pure leisure, paid market work, household work and tertiary time of which only the timing of market work is relevant here. It is defined as all direct job related activities of primary and second jobs, but also comprises time spent on internships, qualification and education on or for the job, job search as well as breaks during the workday and work-related travel time. Commuting time to work is further counted as being work related. From the time diaries, the exact timing of work per day is known which allows me to construct a direct measure of unusual working hours. 


\subsection{Variable Description}

For the determination of wage premia for work at unusual hours, two different definitions will be used from now on. The first refers to shift work and is directly reported by the worker who indicates whether he works morning, evening, rotating or another kind of shift. All these categories are aggregated into a single indicator of shift work. A person belonging to this group will be referred to as self-reported shift worker in the remainder of this study. The relevant reference group consists of all men who do not report to work shifts and I will refer to them as daytime workers.

To go beyond the analysis of shift work in order to understand the importance of the timing of work, I will apply a second definition in this study. It is directly derived from the diary information. In this context, a standard workday is defined for all respondents which lasts from 8 am to $5 \mathrm{pm}$. Making use of the definition of a standard workday, a person is defined to work during unusual hours if more than 30 percent of his working hours lie outside this period $4^{4}$ The respective reference group consists of all other men and will be referred to as men who work during usual working hours from now on.

Table 1 shows the overlap between the different groups of workers. 53 percent of those men who work during unusual hours also report to be shift workers and about 41 percent of the shift workers also work during non-standard hours. Among all those men who do not report working shifts, 12 percent work during non-standard hours. Finally, of those who work normal hours, about 12 percent report shift work.

Table 1: Distribution Between Shift Workers and Those Who Work during Unusual Hours and the Respective Reference Groups.

\begin{tabular}{l|cc|r}
\hline \hline & \multicolumn{2}{|c|}{ reported } & \\
& $\begin{array}{c}\text { shift } \\
\text { workers }\end{array}$ & daytime & \\
& workers & $\mathrm{N}$ \\
\hline unusual hours & 406 & 358 & 764 \\
standard hours & 576 & 2664 & 3238 \\
\hline $\mathrm{N}$ & 980 & 3022 & 4002 \\
\hline \hline
\end{tabular}

In addition to the distinctive advantages, this dataset also has some shortcomings. The exact amount of net monthly earnings is only available for about 70 percent of the respondents. All other

\footnotetext{
${ }^{4}$ The Bureau of Labor Statistics (BLS) suggests to define shift work as any schedule in which more than half of the hours fall outside of a period between 8 am and $4 \mathrm{pm}$ (Mellor 1986). Since the focus is laid on full-time employed men only and in order to have a large enough sample, men who work shifts are defined, in contrast to the BLS, if more than 30 percent of working hours lie outside of the standard workday.
} 
workers indicate wages in income brackets. To use this information, I assign the average wage of the income bracket to each of these workers. Men belonging to the highest income group are assigned 1.5 times the minimum value. More problematic is however that detailed information on job characteristics or on the employer are very scarce. This is a drawback to accurately estimate compensating wage differentials for work disamenities because firm characteristics (i.e. firm size) are important determinants to proxy onerous working conditions. The estimation results on wage differentials are therefore likely to be generally downward biased as larger firms tend to pay higher wages, for example, as incentive device to avoid shirking. These firms are also more likely to offer shift work because it is expensive to turn-off the machines during nights. Unfortunately, information on firm size is not available in the data.

I additionally control for some standard predetermined demographic variables that might explain wages but also the choice of such jobs. These explanatory variables comprise the worker's age in 5 categories, his educational attainment in three categories (low, medium (reference category) and high skills), dummies for being married, being a blue-collar worker and living in Western Germany as well as the number of kids, the log of usual weekly working hours.

\subsection{Sample Description}

General descriptive statistics are displayed in table 2 for all workers but also separately for shift and daytime workers. Among the shift workers, 14 percent work the morning shift, about 1 percent the evening/night shift, 74 percent the rotating shift and 11 percent another kind of shift. About 25 percent of all men in the sample report that they work shifts which exceeds the German average of 15 percent for the entire population for the year 2001. In addition, 19 percent of the sample men work during unusual hours and about 41 percent of these additionally report to work shifts.

Table 2 further shows differences in the composition of the sample groups. Shift workers and men with unusual hours are less educated and are found to have slightly more kids. Furthermore, these men are less likely to live in the Western part of Germany and net average hourly incomes are slightly higher for daytime workers. However, since these men are amongst others older and better educated, a comparison of net mean wages between the groups is not very informative.

Not only are shift workers and men who work during unusual hours very different from the respective reference group but the two groups differ considerably themselves. Men who work during unusual hours are generally better educated than self-reported shift workers. However, they are slightly less likely to be married, have more kids and are slightly more likely to live in Eastern Ger- 
Table 2: Summary Statistics.

\begin{tabular}{|c|c|c|c|c|c|}
\hline & $\begin{array}{c}\text { all } \\
\text { workers } \\
(1)\end{array}$ & $\begin{array}{c}\text { rep. } \\
\text { shift wrk } \\
(2)\end{array}$ & $\begin{array}{c}\text { unus. } \\
\text { wrk hrs } \\
(3)\end{array}$ & $\begin{array}{c}\text { rep. } \\
\text { day wrk } \\
(4)\end{array}$ & $\begin{array}{c}\text { normal } \\
\text { wrk hrs } \\
\text { (5) }\end{array}$ \\
\hline \multicolumn{6}{|l|}{ work information: } \\
\hline unusual wrk hours & $\begin{array}{c}0.191 \\
(0.393)\end{array}$ & $\begin{array}{c}0.414 \\
(0.493)\end{array}$ & $\begin{array}{l}1.000 \\
(0.000)\end{array}$ & $\begin{array}{c}0.118 \\
(0.323)\end{array}$ & $\begin{array}{c}0.000 \\
(0.000)\end{array}$ \\
\hline shift work & $\begin{array}{c}0.245 \\
(0.430)\end{array}$ & $\begin{array}{l}1.000 \\
(0.000)\end{array}$ & $\begin{array}{c}0.531 \\
(0.499)\end{array}$ & $\begin{array}{c}0.000 \\
(0.000)\end{array}$ & $\begin{array}{c}0.177 \\
(0.382)\end{array}$ \\
\hline rotating shifts & $\begin{array}{c}0.186 \\
(0.389)\end{array}$ & $\begin{array}{l}1.000 \\
(0.000)\end{array}$ & $\begin{array}{c}0.476 \\
(0.500)\end{array}$ & $\begin{array}{c}0.000 \\
(0.000)\end{array}$ & $\begin{array}{c}0.121 \\
(0.326)\end{array}$ \\
\hline blue-collar worker & $\begin{array}{c}0.404 \\
(0.491)\end{array}$ & $\begin{array}{c}0.727 \\
(0.446)\end{array}$ & $\begin{array}{c}0.545 \\
(0.498)\end{array}$ & $\begin{array}{c}0.300 \\
(0.458)\end{array}$ & $\begin{array}{c}0.371 \\
(0.483)\end{array}$ \\
\hline \multicolumn{6}{|l|}{ personal characteristics: } \\
\hline age & $\begin{array}{l}43.850 \\
(7.078)\end{array}$ & $\begin{array}{l}43.222 \\
(7.471)\end{array}$ & $\begin{array}{l}43.173 \\
(8.058)\end{array}$ & $\begin{array}{l}44.053 \\
(8.256)\end{array}$ & $\begin{array}{l}44.010 \\
(8.076)\end{array}$ \\
\hline low skilled & $\begin{array}{c}0.021 \\
(0.143)\end{array}$ & $\begin{array}{c}0.047 \\
(0.212)\end{array}$ & $\begin{array}{c}0.035 \\
(0.185)\end{array}$ & $\begin{array}{c}0.012 \\
(0.110)\end{array}$ & $\begin{array}{c}0.017 \\
(0.130)\end{array}$ \\
\hline medium skilled & $\begin{array}{c}0.561 \\
(0.496)\end{array}$ & $\begin{array}{c}0.788 \\
(0.409)\end{array}$ & $\begin{array}{c}0.624 \\
(0.485)\end{array}$ & $\begin{array}{c}0.488 \\
(0.500)\end{array}$ & $\begin{array}{c}0.547 \\
(0.498)\end{array}$ \\
\hline high skilled & $\begin{array}{c}0.415 \\
(0.493)\end{array}$ & $\begin{array}{c}0.165 \\
(0.372)\end{array}$ & $\begin{array}{c}0.338 \\
(0.473)\end{array}$ & $\begin{array}{c}0.496 \\
(0.500)\end{array}$ & $\begin{array}{c}0.434 \\
(0.496)\end{array}$ \\
\hline married & $\begin{array}{c}0.820 \\
(0.385)\end{array}$ & $\begin{array}{c}0.837 \\
(0.370)\end{array}$ & $\begin{array}{c}0.792 \\
(0.406)\end{array}$ & $\begin{array}{c}0.814 \\
(0.389)\end{array}$ & $\begin{array}{c}0.826 \\
(0.379)\end{array}$ \\
\hline \multicolumn{6}{|l|}{ household information: } \\
\hline \# of kids & $\begin{array}{c}1.377 \\
(1.028)\end{array}$ & $\begin{array}{c}1.399 \\
(1.009)\end{array}$ & $\begin{array}{c}1.399 \\
(1.077)\end{array}$ & $\begin{array}{c}1.370 \\
(1.034)\end{array}$ & $\begin{array}{c}1.372 \\
(1.016)\end{array}$ \\
\hline Western Germany & $\begin{array}{c}0.821 \\
(0.384)\end{array}$ & $\begin{array}{c}0.827 \\
(0.385)\end{array}$ & $\begin{array}{c}0.810 \\
(0.392)\end{array}$ & $\begin{array}{c}0.820 \\
(0.385)\end{array}$ & $\begin{array}{c}0.823 \\
(0.381)\end{array}$ \\
\hline observations & 4002 & 980 & 764 & 3022 & 3238 \\
\hline
\end{tabular}

Standard deviations are given in parentheses.

many. Self-reported shift workers earn lower hourly wages but due to differences in educational levels, a mean comparison is again not meaningful.

In addition to compositional differences of shifts workers or men with unusual hours, table 3 reports the respective incidence by occupation group. Sample men who work shifts are predominantly employed as unskilled labor, packers, in metal production, as machine operating, in mining, the food industry and in medical occupations. In contrast, the incidence is least likely in leather processing, management, agriculture, office and social service occupations. Men who work during unusual hours are predominantly unskilled labor, they work in mining, paper and 
Table 3: Mean Incidence of Shift Work or Work During Unusual Hours by Occupation.

\begin{tabular}{l|cccc}
\hline \hline & \multicolumn{2}{|c}{ reported shift work } & \multicolumn{2}{c}{ unusual hours } \\
& mean & rank & mean & rank \\
\hline agriculture & 0.045 & 23 & 0.172 & 16 \\
mining & 0.667 & 5 & 0.375 & 2 \\
paper and wood & 0.577 & 8 & 0.354 & 3 \\
metal production and processing & 0.739 & 3 & 0.211 & 13 \\
engineering & 0.331 & 12 & 0.138 & 21 \\
metal construction & 0.279 & 13 & 0.179 & 15 \\
textiles and leather & 0.000 & 25 & 0.000 & 25 \\
food & 0.657 & 6 & 0.229 & 12 \\
construction & 0.192 & 15 & 0.145 & 19 \\
upholsterers & 0.151 & 17 & 0.110 & 23 \\
painters & 0.385 & 11 & 0.286 & 8 \\
packer & 0.767 & 2 & 0.333 & 5 \\
unskilled labor & 1.000 & 1 & 1.000 & 1 \\
machine operators & 0.675 & 4 & 0.338 & 4 \\
engineers, chemists, physicists, etc. & 0.183 & 16 & 0.161 & 17 \\
merchants and traders & 0.122 & 20 & 0.152 & 18 \\
transportation & 0.487 & 9 & 0.299 & 7 \\
management and consulting & 0.025 & 24 & 0.113 & 22 \\
office occupations & 0.056 & 22 & 0.097 & 24 \\
security occupations & 0.438 & 10 & 0.238 & 10 \\
artists and authors & 0.143 & 19 & 0.231 & 11 \\
medicine and health care & 0.622 & 7 & 0.273 & 9 \\
social services & 0.078 & 21 & 0.186 & 14 \\
other service occupations & 0.143 & 18 & 0.333 & 6 \\
others & 0.214 & 14 & 0.143 & 20 \\
\hline \hline
\end{tabular}

wood production, as packers and in other services, in the transportation business and as painters but also in medicine. The least likely occupations of work at unusual hours are textiles and leather production, office occupations but also management, engineering and construction work.

\subsection{The Timing of Market Work}

To make the distinction between the different groups of workers clearer, figure 2 represents the distributions of working hours for self-reported shift and daytime workers (gray) and for men who work during unusual and standard hours (black). The vertical lines represent the standard workday which is derived from time diaries of the entire sample of employed. Since only few of the daytime workers also work during non-standard hours and only a small proportion of men with standard working hours also reports working shifts (see table 1), the working time distributions 
Figure 2: Distribution of Working Hours by Worker Group.

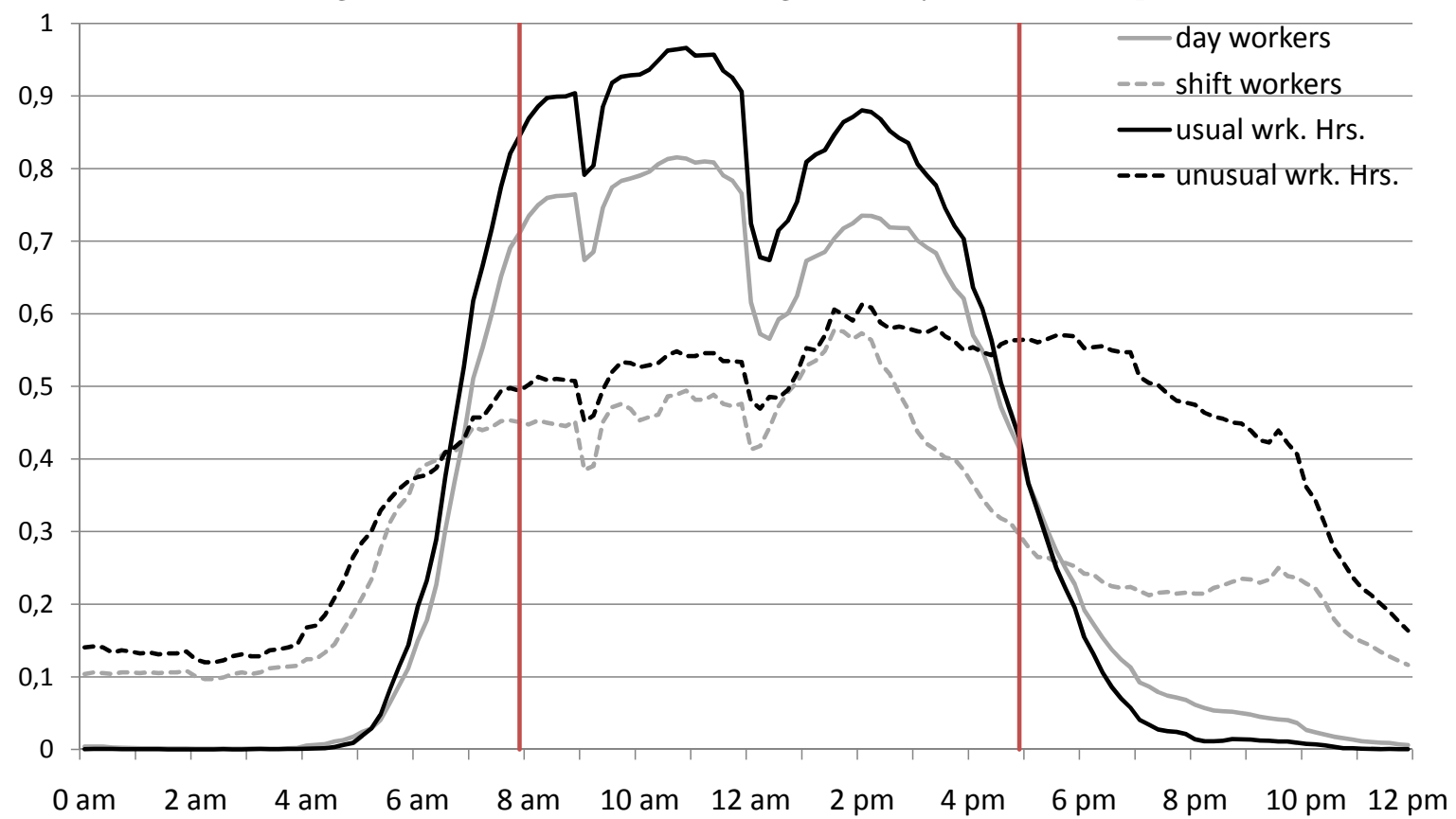

for men in the respective reference groups are relatively similar. In contrast, the distributions of working hours of men who work shifts and of those who work during unusual hours differ across a standard workday, in particular regarding evening hours. The high proportion of shift workers who work during standard hours explain that the average workday of self-reported shift workers is shifted slightly to earlier morning hours as compared to the reference group. During the evening hours, the probability of shift workers to work drastically exceeds the one for the reference group. The work time distribution of those men who work during unusual hours is more evenly distributed across the entire day with a particularly high probability of work during evening hours.

Additional descriptive statistics about the timing of market work and the total number of working hours are reported in table 4 for all men and by group. Work at 9 am and at $3 \mathrm{pm}$ occurs with a probability between 27 and 44 percent for shift workers and men with unusual hours while it tends to be $30-46$ percentage points higher for the relevant reference group. Daytime workers practically do not work during nights but shift workers and men with unusual hours have an average probability of about 13 percent to work at $3 \mathrm{am}$. More interestingly, men who report working shifts have a work probability at $9 \mathrm{pm}$ of 24 percent and men with unusual working hours of even 41 percent. This corroborates the graphical evidence that men with unusual hours are very likely to work during evenings and nights.

Table 4 additionally presents the amount of average actual daily working hours by group. It shows that men with unusual working hours work on average one hour longer than men who 
Table 4: Selected Descriptive Statistics on the Timing of Work and on Aggregate Hours Worked.

\begin{tabular}{|c|c|c|c|c|c|}
\hline & \multirow[t]{2}{*}{ all men } & \multicolumn{2}{|c|}{ reported } & \multicolumn{2}{|c|}{ working hours } \\
\hline & & shift wrk & day wrk & unusual hrs. & usual hrs. \\
\hline \multicolumn{6}{|c|}{ fraction of men at work: } \\
\hline $3 \mathrm{am}$ & 0.024 & 0.106 & 0.001 & 0.129 & 0.000 \\
\hline $9 \mathrm{am}$ & 0.611 & 0.380 & 0.675 & 0.265 & 0.722 \\
\hline $3 \mathrm{pm}$ & 0.644 & 0.435 & 0.703 & 0.377 & 0.708 \\
\hline $9 \mathrm{pm}$ & 0.089 & 0.236 & 0.048 & 0.414 & 0.010 \\
\hline \multicolumn{6}{|c|}{ average daily hours worked: } \\
\hline & $\begin{array}{c}9.14 \\
(2.26)\end{array}$ & $\begin{array}{c}8.89 \\
(2.31) \\
\end{array}$ & $\begin{array}{c}9.20 \\
(2.24)\end{array}$ & $\begin{array}{c}9.80 \\
(3.24)\end{array}$ & $\begin{array}{c}8.96 \\
(1.87) \\
\end{array}$ \\
\hline $\mathrm{N}$ & 4002 & 980 & 3022 & 764 & 3238 \\
\hline
\end{tabular}

Standard deviations in parentheses.

report to work shifts. The Working Time Act (ArbZG) restricts working hours of night shift workers to 8 hours which can be extended to 10 hours per day provided that an average of 8 hours is maintained over a 6 months or 24 week period or alternatively in emergencies and under extraordinary circumstances $5^{5}$ The highly augmented average amount of working hours can additionally be explained by some outliers. People who work very long hours per day fulfill the defining criteria for this group but are compositionally very different. I will account for that in the subsequent analysis. Differences in the average daily working hours of the reference groups are less pronounced.

To find out more about the association between working schedules and earnings, figure $3 \mathrm{de}$ picts differences in the distributions of market work by time slot $t$ for particular income percentiles. The straight black line shows differences between the 90th and the 10th percentile of the earnings distribution. During evenings and night, work is slightly more pronounced for workers in the upper extreme percentile. Yet when time slots around the margins of the standard workday are regarded and in particular during the early morning hours, the figure shows that it is men in the lower extreme percentile who mainly bear the burden of work. The two remaining lines show differences in the timing of market work for the upper and lower half of the earnings distribution. For those earlier hours before the standard workday starts, the figure shows that it is rather workers in the lower part of the wage distribution that have a higher probability to work. The relationship seems to be positive so that with increasing position in the wage distribution, work tends to start later. To summarize the graphical evidence, differences in the allocation of market work are most

\footnotetext{
${ }^{5}$ See also $\$ 6$ of the Arbeitszeitgesetz (ArbZG).
} 
Figure 3: Differences in the Incidence of Market Work by Position in the Wage Distribution.

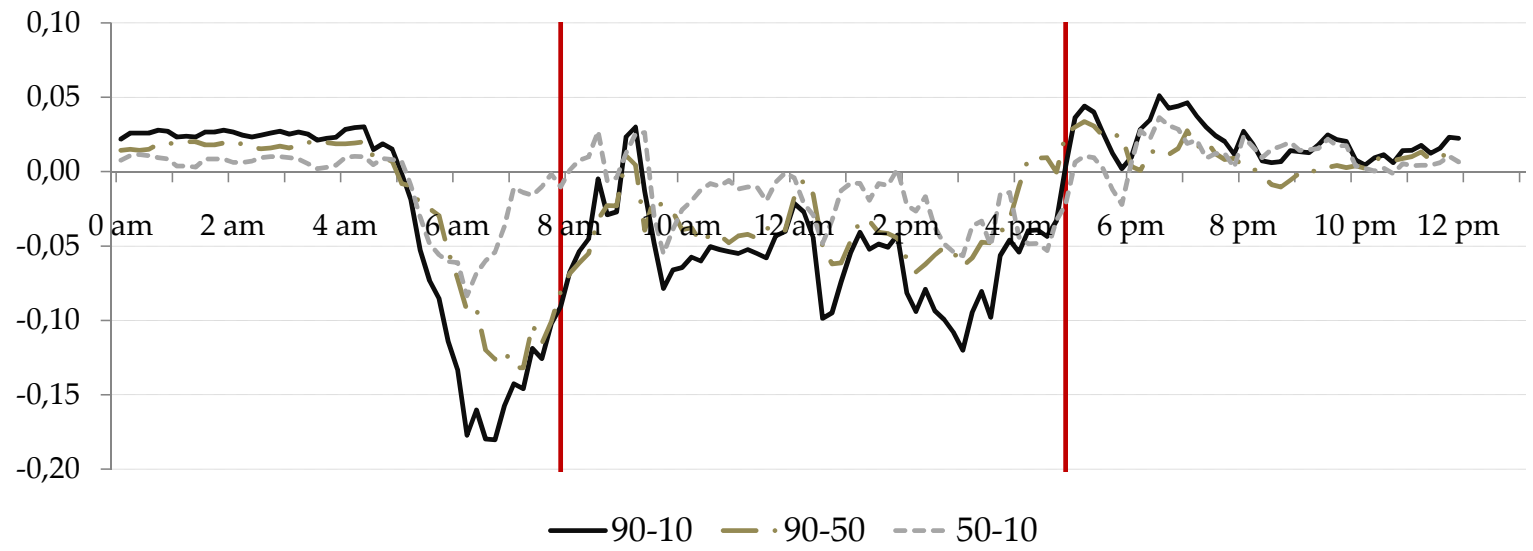

pronounced in the earlier morning hours and seem to be mostly borne by workers in the lower half of the wage distribution.

\section{The Compensation of Onerous Working Conditions}

\subsection{Who Chooses Such Jobs?}

Before analyzing wage premia in more detail, it is important to understand the differences in the choice to work shift or during unusual hours. The resulting determinants can be viewed as first indication about the possible direction of non-random selection based on observable characteristics. Marginal effects from reduced form probits of the choice equation (4) for shift workers (column (1)) and men with unusual hours (column (2)) are presented in table 5 . Moreover, the third column of the table represents the determinants of the reduced-form choice equation of those shift workers who additionally choose to work during non-standard hours. Finally, column (4) presents marginal effects for all men who work during unusual hours and who additionally report to work shifts.

The main exclusion restrictions to identify the selection process but which does not affect wages are adopted and modified from Kostiuk (1990). They are defined as (i) the rate of reported shift work by occupation and sector for the German Time Use Survey of 1991/92 or alternatively, (ii) the rate of unusual working hours by occupation and sector in 1991/92. These exclusion restrictions capture differences in the occupation- and sector-specific tendencies of shift work or work during unusual hours and thus reflect differences in the preferences among workers of the different occupations. The underlying rationale is that men with a stronger dislike for such working conditions sort themselves into jobs that offer lower levels of temporal disamenities as depicted by $P_{0}$ in the first panel of figure 1 
The first line of table 5 shows the marginal effects of the exclusion restrictions of the respective choice equation. It is found to be highly significant which indicates that a higher rate by occupation and industry in 1991/92 is strongly and positively associated with the choice of the relevant job in 2001/02. This suggests that industry and job differences from the beginning of the 1990s are highly correlated with shift choice 10 years later. Thus, they provide a good proxy for the propensity of such working conditions by occupation and industry. Over the decade, not many regulatory changes of working hours or shift work occurred in Germany. The general industry structure is comparable and serves consequently as a good indicator for shift choice in 2001/02. Since the data for the years 1991/92 and 2001/02 are independent cross-sections, the decision to work shifts in 1991/92 is not taken by the same individuals who chose to work shifts or during unusual hours in 2001/02. The exclusion restriction is therefore exogenous. This is an advantage over the exclusion restriction chosen by Kostiuk (1990) who aggregates over those individual decisions that need to be instrumented. This is a serious drawback of his study as the exclusion restriction is not exogenous and does not solve the endogenous job choice.

Regarding other choice determinants, the table shows that shift work is less likely for high skilled workers as well as for men with more kids. Married men as well as workers, who are either younger or older than the reference group, have a higher propensity to work in such jobs. Lower levels of education are associated with a higher probability yet it is not significant. Blue-collar workers tend to be about 15 percent more likely to work some shifts which indicates that low-skilled manual workers have higher tendencies. Men who live in West Germany are furthermore observed to have a slightly yet insignificantly higher probability. As mentioned earlier, the Working Time Act (ArbZG) restricts the daily working hours of night shifts to 8 hours per day which can be extended to 10 only in exceptional cases. This regulation is reflected by the negative coefficient on the number of average weekly working hours. The influence of the Working Time Act is even more sizeable if only evening and night shift workers were considered. The high fraction of workers in rotating teams therefore upward-biases the overall estimates. When only rotating shift workers are regarded, a positive relationship between the number of hours worked and the propensity to work shifts is obtained 6

Column (2) shows the determinants of the choice to work during unusual hours. Since this group of men is very heterogeneous, as mentioned in section 4.2 , only few determinants have a significant impact on job choice. It follows that married men and those between 40 and 50 tend to

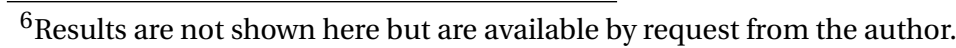


Table 5: Marginal Effects of Probit Estimates of the Selection Equation.

\begin{tabular}{|c|c|c|c|c|}
\hline & $\begin{array}{c}\text { reported } \\
\text { shift status } \\
(1)\end{array}$ & $\begin{array}{c}\text { unusual } \\
\text { wrk hrs } \\
(2)\end{array}$ & $\begin{array}{c}\text { shift w/ } \\
\text { unusual hrs } \\
\text { (3) }\end{array}$ & $\begin{array}{c}\text { unusual } \\
\text { hrs w/ shift } \\
\text { (4) }\end{array}$ \\
\hline \multicolumn{5}{|l|}{ exclusion restrictions } \\
\hline rate of shift work in 1991 & $\begin{array}{l}0.777^{*} \\
(14.79)\end{array}$ & $\begin{array}{l}0.476^{*} \\
(7.98)\end{array}$ & $\begin{array}{l}0.458^{*} \\
(3.41)\end{array}$ & $\begin{array}{l}\text { 1.053* } \\
\text { (11.13) }\end{array}$ \\
\hline \multicolumn{5}{|l|}{ individual characteristics } \\
\hline age: under 30 & $\begin{array}{l}0.058^{*} \\
(1.95)\end{array}$ & $\begin{array}{l}0.008 \\
(0.27)\end{array}$ & $\begin{array}{l}-0.049 \\
(0.57)\end{array}$ & $\begin{array}{l}-0.019 \\
(0.28)\end{array}$ \\
\hline age: 40 - 50 & $\begin{array}{l}0.042^{*} \\
(2.40)\end{array}$ & $\begin{array}{c}-0.031^{*} \\
(1.71)\end{array}$ & $\begin{array}{c}-0.167^{*} \\
(3.51)\end{array}$ & $\begin{array}{l}-0.055 \\
(1.29)\end{array}$ \\
\hline age: 50 - 60 & $\begin{array}{l}0.085^{*} \\
(5.26)\end{array}$ & $\begin{array}{l}-0.026 \\
(1.54)\end{array}$ & $\begin{array}{c}-0.111^{*} \\
(2.62)\end{array}$ & $\begin{array}{l}0.074^{*} \\
(1.73)\end{array}$ \\
\hline age: above 60 & $\begin{array}{l}0.025 \\
(1.39)\end{array}$ & $\begin{array}{l}-0.026 \\
(0.94)\end{array}$ & $\begin{array}{l}-0.009 \\
(0.20)\end{array}$ & $\begin{array}{l}0.028 \\
(0.62)\end{array}$ \\
\hline low skilled & $\begin{array}{l}0.058 \\
(1.53)\end{array}$ & $\begin{array}{l}0.062 \\
(1.61)\end{array}$ & $\begin{array}{l}0.057 \\
(0.82)\end{array}$ & $\begin{array}{l}-0.009 \\
(0.09)\end{array}$ \\
\hline high skilled & $\begin{array}{c}-0.093^{*} \\
(6.55)\end{array}$ & $\begin{array}{l}-0.000 \\
(0.01)\end{array}$ & $\begin{array}{l}0.056 \\
(1.29)\end{array}$ & $\begin{array}{c}-0.139^{*} \\
(4.19)\end{array}$ \\
\hline married & $\begin{array}{l}0.037^{*} \\
(2.11)\end{array}$ & $\begin{array}{c}-0.040^{*} \\
(2.25)\end{array}$ & $\begin{array}{l}-0.075 \\
(1.57)\end{array}$ & $\begin{array}{l}0.029 \\
(0.69)\end{array}$ \\
\hline \multicolumn{5}{|l|}{ household characteristics } \\
\hline \# of kids & $\begin{array}{c}-0.013^{*} \\
(2.06)\end{array}$ & $\begin{array}{c}0.012^{*} \\
(1.72)\end{array}$ & $\begin{array}{c}0.040^{*} \\
(2.31)\end{array}$ & $\begin{array}{c}-0.004 \\
(0.25)\end{array}$ \\
\hline West Germany & $\begin{array}{l}0.017 \\
(1.03)\end{array}$ & $\begin{array}{l}-0.013 \\
(0.82)\end{array}$ & $\begin{array}{l}0.003 \\
(0.06)\end{array}$ & $\begin{array}{l}0.016 \\
(0.41)\end{array}$ \\
\hline \multicolumn{5}{|l|}{ work characteristics } \\
\hline usual wrk. hrs (log) & $\begin{array}{l}-0.041^{*} \\
(2.00)\end{array}$ & $\begin{array}{l}0.075 \\
(0.82)\end{array}$ & $\begin{array}{l}0.277^{*} \\
(2.93)\end{array}$ & $\begin{array}{l}-0.048 \\
(1.05)\end{array}$ \\
\hline blue-collar worker & $\begin{array}{c}0.151^{*} \\
(11.21)\end{array}$ & $\begin{array}{c}0.091^{*} \\
(6.37)\end{array}$ & $\begin{array}{c}0.092^{*} \\
(2.49)\end{array}$ & $\begin{array}{c}0.149^{*} \\
(4.74)\end{array}$ \\
\hline $\begin{array}{l}\text { observations } \\
\text { pseudo } \mathrm{R}^{2}\end{array}$ & $\begin{array}{l}4002 \\
0.224\end{array}$ & $\begin{array}{l}4002 \\
0.045\end{array}$ & $\begin{array}{c}989 \\
0.035\end{array}$ & $\begin{array}{c}719 \\
0.307\end{array}$ \\
\hline
\end{tabular}

Absolute $z$-statistics in parentheses. Standard errors are robust. * indicate significance levels of $10 \%$ or higher.

be significantly less likely to work at unusual hours. It is possible that people accept work during non-standard hours when they are younger and more flexible for career concerns. Men with low educational levels tend to have higher probabilities while the number of kids is positively associated with such working schedules. In addition, blue-collar workers tend to be 9 percent more likely. 
The third column of the table further reports the marginal effects of those shift workers who additionally choose to work during unusual hours. Due to the heterogeneity of these workers, the pseudo $R^{2}$ is very low and only few characteristics have a significant influence. These characteristics are however interesting: I find that shift workers with more kids and those who are blue-collar workers tend to be more likely to work also during unusual hours. In contrast, shift workers above 40 are less likely than prime age men. Finally, the last column reports marginal effects for men who report to work shifts among all those men who work during unusual hours. It is again bluecollar workers who tend to have higher probabilities. Interestingly, also men above 50 tend to have a higher probability to work shifts when they work at unusual hours. Higher levels of education, in contrast, lower the respective probability to choose such jobs.

It can be summarized that the combining element to work in such jobs is to be a blue-collar worker. In addition, it is predominantly workers with lower levels of education who tend to be more likely.

\subsection{Compensation and Sample Selection}

To work shifts or during unusual hours can generally be considered as disamenity because it entails lack of sleep, higher levels of stress and higher risks of accidents at the workplace (Folkard and Tucker 2003: Minors et al. 1986) which might harm individual work efficiency and thus productivity (Hamermesh, 1999a). In addition, it is well established that workers who are exposed to work at non-standard hours have higher risks of gastric ulcer (Tüchsen et al. 1994), cardiovascular diseases (Bøggild and Knutsson, 1999) and even of cancer (Davis and Mirick, 2006). According to the theory of compensating wage differentials (Smith, 1776, Rosen, 1987) such onerous working conditions should be better remunerated in order to attract workers to accept such jobs despite the augmented risk to health. Differences in tastes for such working conditions across the population determine the size of the realized average wage premium which is paid as compensation.

Simple OLS estimates give a first naive indication about the size of wage premia and are reported in the first row of table 6 . Accordingly, the wage differential associated with shift work is 4 percent on average. Estimated net hourly wage premia are more pronounced for men who work during non-standard hours. They are found to receive on average 6.2 percent higher net hourly wages as compared to the reference group. These simple associations suggest that German workers earn significant monetary compensations when they are exposed to shift work or to work at unusual hours. All additional wage determinants are reported in table 9 . 
Table 6: Results from Wage Equations Estimated by OLS and Treatment Effects Models. Dependent Variable: Log Net Hourly Wages.

\begin{tabular}{l|cc}
\hline \hline & $\begin{array}{c}\text { reported } \\
\text { shift wrk }\end{array}$ & $\begin{array}{c}\text { unusual } \\
\text { wrk. hrs. }\end{array}$ \\
\hline OLS & & \\
\hline indicator & $\begin{array}{c}0.040^{*} \\
(3.62)\end{array}$ & $\begin{array}{c}0.062^{*} \\
(4.78)\end{array}$ \\
\hline sample selection model & & \\
\hline indicator & $0.103^{*}$ & $-0.104^{*}$ \\
& $(2.72)$ & $(1.34)$ \\
inverse Mills ratio $(\hat{\lambda})$ & $-0.040^{*}$ & $0.096^{*}$ \\
& $(1.76)$ & $(2.16)$ \\
\hline $\mathrm{N}$ & 4002 & 4002 \\
\hline \hline
\end{tabular}

Absolute $t$-statistics are given in parentheses. Standard errors are robust. * indicates significance levels of $10 \%$ or higher.

If the choice to work shifts or during non-standard hours is non-random, estimates obtained from OLS are biased with sign and magnitude of this bias depending on the nature of the underlying selection process. If additional abilities that are important to determine wages are not entirely captured by the exogenous variables but are further reflected by higher wages, the error terms of the wage equation would be positive. In addition, if workers are more likely to work in such jobs because of the higher associated wage rate, also the error term of the choice equation would be positive as well as the covariance between the two equations. In other words, a positive selection into such jobs occurs or vice versa.

To account for the potential non-random selection, the choice equation presented earlier will be used and will be estimated simultaneously with wage equation. The inverse Mills ratio is derived from the parameters estimates of the choice equation and is included as additional explanatory variable in the wage equation. The estimate of the inverse Mills ratios are presented in addition to the selectivity corrected estimate of the average wage differentials in the second and third line of table 6. The inverse Mill's ratio indicates sign and magnitude of the potential selection process. A negative estimate indicates that men who choose to work shifts or during unusual hours tend to have more unfavorable characteristics and vice versa.

The estimates of the inverse Mill's ratio suggest that shift workers are negatively selected workers with less favorable labor market characteristics. This suggests that OLS estimates are downward 
Table 7: Top 5 Occupations of Employees with Unusual Hours and Associated Average Daily Hours of Market Work.

\begin{tabular}{c|lcllc}
\hline \hline & \multicolumn{2}{|c}{ unusual hours } & \multicolumn{2}{c}{ standard hours } \\
& occupation & hours & occupations & hours \\
\hline 1st & transportation & 9.91 & managements, consult- & 8.93 \\
& & & ing & \\
2nd & security occupations & 8.12 & metal engineering & 8.83 \\
3rd & management, consulting & 10.59 & $\begin{array}{l}\text { engineers, chemists, } \\
\text { physicists }\end{array}$ & 8.68 \\
4th & engineers, chemists, & 9.36 & office occupations & 8.22 \\
5th & $\begin{array}{l}\text { physicists } \\
\text { metal engineering }\end{array}$ & 8.47 & social occupations & 7.13 \\
\hline \hline
\end{tabular}

biased and that it is crucial to account for it. These workers would earn lower wages for comparable daytime work and select themselves into work with undesirable schedules because they can supplement their incomes that way. The selectivity corrected estimates of the wage premium from treatment effects models, as shown in table 6, reveal that shift workers earn on average 10.3 percent more per hour. This wage differential is sizeable and is evidence that these workers would rather avoid such jobs if possible but accept them because of the substantial monetary compensation.

According to the estimate of the inverse Mill's ratio, men who work during unusual hours tend to be positively selected group of workers as shown be the second column of table 6 , The estimate is positive and significant. This result indicates that men with favorable labor market characteristics choose to work at unusual hours. Consequently, OLS estimates are upward biased and the sign of the selectivity corrected estimates turns negative. This finding is however counter-intuitive.

As noted earlier, the coefficient estimates are likely to be driven by a small group of workers with very specific preferences and above average working hours. In this case, these coefficient estimates are likely to be an artifact that highly depends on the construction of the indicator. If men who work very long hours fulfill the criteria mentioned above and are thus allocated to this group, the results obtained are not representative. Table 7 underlines this hypothesis and depicts the top five occupations in which workers of the respective groups are most likely to be represented as well as the respective average hours of market work. Those men who are defined to work at unusual hours have the highest probabilities to be employed in such occupations that are associated with longer average working hours. The top five occupations comprise transportation, security, 
management and consulting but also engineering jobs. Many of these require higher skill levels which explains the positive selection according to table 6 . It follows that men working in these occupations strongly drive these results but the respective workers might have entirely different preferences. Moreover, it is very likely that for these workers additional non-pecuniary aspects matter that also drive the choice of working hours. To account for this problem, I will henceforth restrict the daily amount of market work for this group of workers to not exceed 10 hours. In contrast to that, the working hours of the top 5 occupations for those men who work during normal hours are more homogeneous as shown by the table.

Table 8: Estimates for Men who Work at Unusual Hours but Who Work Less than 10 Hours per Day.

\begin{tabular}{|c|c|c|c|}
\hline & $\begin{array}{l}\text { unusual } \\
\text { wrk hrs }\end{array}$ & $\begin{array}{l}\text { shift wrk w/ } \\
\text { unusual hrs }\end{array}$ & $\begin{array}{c}\text { unusual hrs } \\
\text { w/ shift }\end{array}$ \\
\hline \multicolumn{4}{|l|}{ OLS } \\
\hline indicator & $\begin{array}{l}0.067^{*} \\
(4.31)\end{array}$ & $\begin{array}{l}0.068^{*} \\
(3.53)\end{array}$ & $\begin{array}{l}0.054 \\
(1.47)\end{array}$ \\
\hline \multicolumn{4}{|l|}{ sample selection model } \\
\hline indicator & $\begin{array}{l}0.090 \\
(1.09)\end{array}$ & $\begin{array}{l}-0.327 \\
(1.20)\end{array}$ & $\begin{array}{l}0.124 \\
(1.10)\end{array}$ \\
\hline inverse Mills ratio $(\hat{\lambda})$ & $\begin{array}{l}-0.013 \\
(0.28)\end{array}$ & $\begin{array}{l}0.244 \\
(1.45)\end{array}$ & $\begin{array}{l}-0.045 \\
(0.71)\end{array}$ \\
\hline $\mathrm{N}$ & 2931 & 779 & 464 \\
\hline
\end{tabular}

Absolute $t$-values are given in parentheses. Standard errors are robust. * indicates significance levels of $10 \%$ or higher.

The more representative estimates of the wage differentials obtained from OLS and treatment effects models for men who work with unusual schedules but not more than 10 hours per day are reported in the first column of table 8 . The estimates reveal that the now excluded workers have strongly biased the previous estimates. By restricting the number of working hours results in more reasonable and intuitive coefficient estimates. Accordingly, men with such working schedules earn wage premia of 11.1 percent which are sizeable but only inaccurately estimated. Moreover, these workers are negatively selected yet the selection term is not significant.

The table further shows wage differentials and the selection term for shift workers who work at unusual hours (column 2) and for men who work at unusual hours and who additionally work shifts (column 3). Simple OLS estimates show that shift workers who work during unusual hours tend to earn on average about 6.8 percent higher net hourly wages. In contrast, simple wage premia for men with unusual working hours who additionally report working shifts tend to be lowest and insignificant and amount to 5.4 percent. 
The lower panel presents selectivity corrected estimates. The inverse Mill's ratio is not accurately estimated and is hence insignificant in both cases. The sign of these estimates is however interesting and reveals that among all shift workers those who work at unusual hours tend to be positively selected. Among the workers who work at unusual hours, those who also report to work shift, tend to have less favorable labor market characteristics. The estimates are however too large in size which indicates that the number of observation is too low to allow for a correct estimation of the coefficient estimates.

The remaining wage determinants are reported in table 9. Age has no significant influence on wages. Only workers under the age of 30 earn significantly lower wages than prime-age men. Yet, these workers are a selected group that consists of a high fraction of men with lower levels of education and hence lower average wages who started their work life early. Better educated men with university degrees enter the labor market not until the age of 25. Married men and men with more kids, who live in Western Germany are found to earn significantly higher net hourly wages. In contrast, blue-collar workers and men with lower levels of education have lower earnings. In addition, men with longer average weekly working hours are found to earn significantly lower net hourly wages which might be evidence that overtime hours are on average not remunerated in terms of additional wages but are compensated differently.

Moreover, OLS estimates of the influence of explanatory variables and those obtained from treatment effects models as reported in columns (2) and (6) show to be relatively robust. I find that the selectivity-corrected estimates only change slightly for the skill groups and for blue-collar workers. This indicates that these are the determinants that are predominantly responsible for selection on observables. Since shift workers are negatively selected, the low-skill penalty increases slightly and so does the compensation for blue-collar work when selection is accounted for. When men who work at unusual hours are regarded wage penalties of lower skills slightly increase for lower skills but are unaffected in the case of blue-collar work.

\subsection{Can Wage Equations Be Pooled?}

If the determinants are differently valued in terms of wages for the different groups of workers, pooling wage equations into one single equation would result in overestimated wage premia (Lanfranchi et al. 2002). Poolability shall therefore be tested in more detail in this section. Columns (3) and (4) additionally report coefficient estimates from switching regression models with endogenous switching for separate wage equations for day and shift workers; columns (7) and (8) represent separate wage determinants for men who work usual and unusual hours. 
Table 9: Estimation Results from OLS and Sample Selection Models. Dependent Variable: Log Net Hourly Wages.

\begin{tabular}{|c|c|c|c|c|c|c|c|c|}
\hline & \multicolumn{4}{|c|}{ reported } & \multicolumn{4}{|c|}{ unusual } \\
\hline & \multirow{2}{*}{$\begin{array}{l}\text { OLS } \\
\text { all }\end{array}$} & \multicolumn{3}{|c|}{ sample selection } & \multirow{2}{*}{$\begin{array}{c}\text { OLS } \\
\text { all }\end{array}$} & \multicolumn{3}{|c|}{ sample selection } \\
\hline & & all & day & shift & & all & usual & unus. \\
\hline & (1) & (2) & (3) & (4) & (5) & (6) & (7) & (8) \\
\hline \multicolumn{9}{|l|}{ shift indicator } \\
\hline shift indicator & $\begin{array}{l}0.040^{*} \\
(3.62)\end{array}$ & $\begin{array}{c}0.103^{*} \\
(2.72)\end{array}$ & & & $\begin{array}{c}0.067^{*} \\
(4.31)\end{array}$ & $\begin{array}{l}0.090 \\
(1.09)\end{array}$ & & \\
\hline inv. Mills ratio & & $\begin{array}{c}-0.058^{*} \\
(3.02)\end{array}$ & $\begin{array}{c}-0.086^{*} \\
(2.57)\end{array}$ & $\begin{array}{c}-0.039 \\
(1.16)\end{array}$ & & $\begin{array}{l}-0.013 \\
(0.28)\end{array}$ & $\begin{array}{c}-0.123^{*} \\
(1.84)\end{array}$ & $\begin{array}{c}-0.035 \\
(0.41)\end{array}$ \\
\hline \multicolumn{9}{|c|}{ individual characteristics } \\
\hline age: under 30 & $\begin{array}{c}-0.200^{*} \\
(6.84)\end{array}$ & $\begin{array}{c}-0.201^{*} \\
(8.13)\end{array}$ & $\begin{array}{c}-0.230^{*} \\
(6.76)\end{array}$ & $\begin{array}{c}-0.049 \\
(1.10)\end{array}$ & $\begin{array}{c}-0.235^{*} \\
(6.82)\end{array}$ & $\begin{array}{c}-0.234^{*} \\
(8.66)\end{array}$ & $\begin{array}{c}-0.213^{*} \\
(5.69)\end{array}$ & $\begin{array}{c}-0.315^{*} \\
(3.24)\end{array}$ \\
\hline age: $40-50$ & $\begin{array}{l}0.006 \\
(0.42)\end{array}$ & $\begin{array}{l}0.004 \\
(0.25)\end{array}$ & $\begin{array}{l}0.012 \\
(0.71)\end{array}$ & $\begin{array}{l}0.006 \\
(0.24)\end{array}$ & $\begin{array}{l}0.019 \\
(1.21)\end{array}$ & $\begin{array}{l}0.020 \\
(1.22)\end{array}$ & $\begin{array}{l}0.018 \\
(0.97)\end{array}$ & $\begin{array}{c}-0.001 \\
(0.02)\end{array}$ \\
\hline age: 50 - 60 & $\begin{array}{l}-0.002 \\
(0.19)\end{array}$ & $\begin{array}{c}-0.009 \\
(0.64)\end{array}$ & $\begin{array}{l}0.017 \\
(0.86)\end{array}$ & $\begin{array}{l}0.001 \\
(0.04)\end{array}$ & $\begin{array}{l}0.009 \\
(0.62)\end{array}$ & $\begin{array}{l}0.009 \\
(0.60)\end{array}$ & $\begin{array}{c}-0.012 \\
(0.74)\end{array}$ & $\begin{array}{l}0.092 \\
(2.11)\end{array}$ \\
\hline age: above 60 & $\begin{array}{l}0.053^{*} \\
(3.77)\end{array}$ & $\begin{array}{c}0.052^{*} \\
(3.80)\end{array}$ & $\begin{array}{l}0.067^{*} \\
(3.91)\end{array}$ & $\begin{array}{l}0.021 \\
(0.79)\end{array}$ & $\begin{array}{c}0.065^{*} \\
(3.81)\end{array}$ & $\begin{array}{c}0.066^{*} \\
(4.23)\end{array}$ & $\begin{array}{c}0.055^{*} \\
(3.00)\end{array}$ & $\begin{array}{l}0.098 \\
(2.15)\end{array}$ \\
\hline low skilled & $\begin{array}{c}-0.204^{*} \\
(4.86)\end{array}$ & $\begin{array}{c}-0.215^{*} \\
(6.22)\end{array}$ & $\begin{array}{c}-0.247^{*} \\
(3.19)\end{array}$ & $\begin{array}{c}-0.127^{*} \\
(3.50)\end{array}$ & $\begin{array}{c}-0.215^{*} \\
(4.02)\end{array}$ & $\begin{array}{c}-0.221^{*} \\
(5.17)\end{array}$ & $\begin{array}{c}-0.181^{*} \\
(2.67)\end{array}$ & $\begin{array}{c}-0.213 \\
(1.52)\end{array}$ \\
\hline high skilled & $\begin{array}{l}0.217^{*} \\
(17.93)\end{array}$ & $\begin{array}{l}0.225^{*} \\
(18.87)\end{array}$ & $\begin{array}{l}0.193^{*} \\
(11.46)\end{array}$ & $\begin{array}{l}0.117^{*} \\
(3.26)\end{array}$ & $\begin{array}{l}0.195^{*} \\
(14.78)\end{array}$ & $\begin{array}{l}0.196^{*} \\
(15.76)\end{array}$ & $\begin{array}{l}0.178^{*} \\
(11.83)\end{array}$ & $\begin{array}{c}0.239 * \\
(5.23)\end{array}$ \\
\hline married & $\begin{array}{l}0.190^{*} \\
(12.37)\end{array}$ & $\begin{array}{l}0.189^{*} \\
(13.32)\end{array}$ & $\begin{array}{c}0.206^{*} \\
(11.15)\end{array}$ & $\begin{array}{l}0.170^{*} \\
(5.76)\end{array}$ & $\begin{array}{l}0.190^{*} \\
(10.63)\end{array}$ & $\begin{array}{l}0.190^{*} \\
(11.94)\end{array}$ & $\begin{array}{c}0.185^{*} \\
(9.59)\end{array}$ & $\begin{array}{c}0.183^{*} \\
(2.95)\end{array}$ \\
\hline \multicolumn{9}{|c|}{ household characteristics } \\
\hline \# of kids & $\begin{array}{c}0.044^{*} \\
(7.70)\end{array}$ & $\begin{array}{c}0.044^{*} \\
(8.26)\end{array}$ & $\begin{array}{l}0.035^{*} \\
(4.95)\end{array}$ & $\begin{array}{c}0.054^{*} \\
(4.90)\end{array}$ & $\begin{array}{c}0.039^{*} \\
(6.20)\end{array}$ & $\begin{array}{c}0.039^{*} \\
(6.66)\end{array}$ & $\begin{array}{c}0.043^{*} \\
(5.99)\end{array}$ & $\begin{array}{l}0.024 \\
(1.37)\end{array}$ \\
\hline West German & $\begin{array}{l}0.373^{*} \\
(27.59)\end{array}$ & $\begin{array}{l}0.371^{*} \\
(29.16)\end{array}$ & $\begin{array}{l}0.373^{*} \\
(22.94)\end{array}$ & $\begin{array}{l}0.360^{*} \\
(15.68)\end{array}$ & $\begin{array}{l}0.347^{*} \\
(22.15)\end{array}$ & $\begin{array}{l}0.348^{*} \\
(23.49)\end{array}$ & $\begin{array}{l}0.337^{*} \\
(18.55)\end{array}$ & $\begin{array}{c}0.357^{*} \\
(9.22)\end{array}$ \\
\hline \multicolumn{9}{|l|}{ work characteristics } \\
\hline log wrk hrs & $\begin{array}{l}-0.909^{*} \\
(24.15)\end{array}$ & $\begin{array}{l}-0.907^{*} \\
(46.26)\end{array}$ & $\begin{array}{l}-0.911^{*} \\
(22.94)\end{array}$ & $\begin{array}{l}-1.018^{*} \\
(20.82)\end{array}$ & $\begin{array}{l}-0.938^{*} \\
(23.13)\end{array}$ & $\begin{array}{l}-0.938^{*} \\
(40.97)\end{array}$ & $\begin{array}{l}-0.913^{*} \\
(16.94)\end{array}$ & $\begin{array}{l}-1.013^{*} \\
(27.86)\end{array}$ \\
\hline blue-collar & $\begin{array}{l}-0.259^{*} \\
(22.26)\end{array}$ & $\begin{array}{l}-0.276^{*} \\
(18.29)\end{array}$ & $\begin{array}{c}-0.207^{*} \\
(6.22)\end{array}$ & $\begin{array}{c}-0.201^{*} \\
(6.47)\end{array}$ & $\begin{array}{l}-0.263^{*} \\
(20.24)\end{array}$ & $\begin{array}{l}-0.266^{*} \\
(17.04)\end{array}$ & $\begin{array}{l}-0.268^{*} \\
(13.52)\end{array}$ & $\begin{array}{c}-0.203^{*} \\
(2.02)\end{array}$ \\
\hline constant & $\begin{array}{l}5.344^{*} \\
(37.69)\end{array}$ & $\begin{array}{l}5.329 * \\
(70.64)\end{array}$ & $\begin{array}{c}5.409^{*} \\
(36.14)\end{array}$ & $\begin{array}{c}5.801^{*} \\
(30.9)\end{array}$ & $\begin{array}{l}5.484^{*} \\
(35.89)\end{array}$ & $\begin{array}{l}5.480 * \\
(61.75)\end{array}$ & $\begin{array}{l}5.459^{*} \\
(26.64)\end{array}$ & $\begin{array}{l}5.819^{*} \\
(13.69)\end{array}$ \\
\hline observations & 4002 & 4002 & 3022 & 980 & 2931 & 2931 & 2467 & 464 \\
\hline
\end{tabular}

Absolute $t$-values are given in parentheses. Standard errors are robust. ${ }^{*}$ indicates significance levels of $10 \%$. or higher

Simple $F$-tests for the equality of all coefficient estimates of the separate wage equations are performed. The respective $F$-statistic is presented in the last line of table 10 . It takes the value of 29.66 and has a $p$-value of 0.002 when testing for equality of remunerations between day and shift workers. The hypothesis of equal coefficients can be hence rejected for shift workers. It follows that the wage determinants are different between shift workers and men who do not report to work shifts and a switching regression with endogenous switching is the appropriate estimation method. 
When men with unusual working hours are concerned, the $F$-statistic is 20.40 with a p-value of 0.040. It follows, that also in this case, the hypothesis that a similar remuneration for both groups of workers can be rejected at reasonable significance levels. Pooling both equations is therefore not appropriate and estimation by treatment effects models would deliver overestimated wage differentials.

Table 10: $P$-Values for Tests of Equality of Single Coefficient Estimates between Separate Equations by Group.

\begin{tabular}{lcc}
\hline \hline & shift workers & unusual hrs. \\
\hline single coefficient tests: & & \\
\hline age: under 30 & 0.0013 & 0.3284 \\
age: 40 - 50 & 0.8393 & 0.6954 \\
age: 50 - 60 & 0.6155 & 0.0259 \\
age: above 60 & 0.1413 & 0.3785 \\
low skilled & 0.1684 & 0.8387 \\
high skilled & 0.0534 & 0.2101 \\
married & 0.2953 & 0.9752 \\
\# of kids & 0.1500 & 0.3368 \\
West German & 0.6541 & 0.6405 \\
usual wrk. hrs (log) & 0.0896 & 0.1073 \\
blue-collar worker & 0.8985 & 0.6726 \\
\hline test for all coefficients simultaneously: \\
\hline \multicolumn{2}{l}{$F(14,4002 / 2932)$} & 0.0018 \\
\hline \hline \multicolumn{2}{l}{$N=4002$ in the case of shift workers; $N=2932$ when } \\
men with unusual hours are considered whose work- \\
ing hours do not exceed 10 per day.
\end{tabular}

To find out which wage of the wage determinants differ significantly for shift and daytime workers, table 10 further reports t-tests of the equality of each single coefficient between the separate equations. In the case of men with unusual working hours, almost no wage determinant differs significantly between the groups. The only exception is that the remuneration of low skills differs. Such men earn wage penalties of 18 percent when they work during standard working hours. In contrast, being at work during non-standard hours is associated with an even larger negative wage differential of 21 percent which is not significant though. In addition, the remuneration of longer average weekly working hours differs marginally between the groups. Also in this case, wage penalties are larger for men who work at unusual hours which might reflect the stronger regulations of working hours by the Working Time Act $(A r b Z G)$ in Germany. Although only few wage determinants differ between the wage equations of both groups, the overall F-tests suggests that it is more 
appropriate to investigate them based on a switching regression model with endogenous switching.

In the case of shift workers, as shown by table 10 , more explanatory variables differ between the separate regressions. Men under the age of 30 receive drastic wage penalties for daytime work as compared with the reference group. In contrast, the wage penalty for these men is insignificant and rather in the case of shift workers. Table 5 additionally showed that these workers have a higher probability to choose to work shifts. The lower wage penalties are thus an indication for compensating wages to attract such workers (See also Hamermesh 1999b for the US). In addition, higher levels of education are significantly better paid for daytime work. This corroborates the assumption of a higher earnings potential of these workers who thus avoid to work during non-standard hours. Finally, shift workers have generally lower average weekly working hours. Here again, the regulation of the Working Time Act (ArbZG) might be one possible reason as it strongly restricts daily working hours in particular of night shifts.

The overall F-test rejects the equality of remunerations between all groups of workers. It follows that wage equations shall be estimated separately. The appropriate estimation method is thence a switching regression model with endogenous switching. Columns (3) and (4) of table 9 and (7) and (8) report the respective selection terms for the separate estimations. Consequently, shift workers but also men who work during unusual hours are negatively selected yet the selection term is not significant in these cases. In contrast, men who work during daytime hours but even to a greater extent those with standard working schedules are positively selected which suggests that they sort themselves into work during the day because of preferences or comparative advantage. Moreover, these men have large unmeasured components of daytime wages and can hence afford to use some of their earnings power to avoid working shifts (Hamermesh 1999b). Shift workers and men with unusual schedules, in contrast, are not less suited for daytime work yet they seem to choose such jobs because of the associated wage premium (Kostiuk, 1990, Lanfranchi et al. 2002).

\subsection{Wage Differentials by Wage Quantile}

To get a better picture and to better understand the wage differential over the wage distribution, results obtained from quantile regressions for each 5th-percentile with 50 replications will be investigated. Unfortunately, a routine to control for sample selection is not readily available so that non selectivity corrected estimates are reported here. Yet, as shown earlier in this paper, since shift workers are significantly negatively selected, overall wage differentials will be downward biased. 
The coefficient estimates from quantile regressions must therefore be interpreted as lower limits. Since predominantly men with less favorable characteristics choose to work shifts, the downward bias will be stronger for men in the upper quantiles of the earnings distribution. Moreover, men with unusual working schedules who work not more than 10 hours per day do not tend to have systematically less unfavorable characteristics so that the estimates reported here are sufficient.

Figure 4: Distribution of Working Hours by Worker Group.

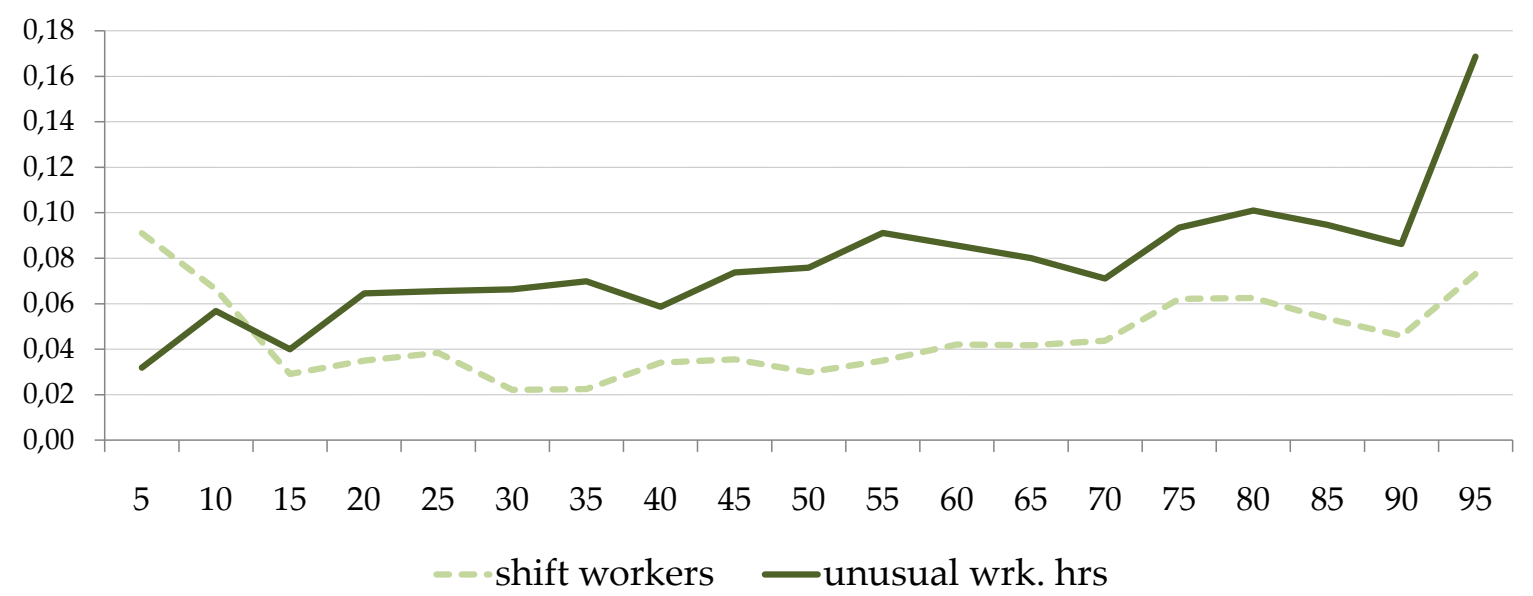

Figure 4 graphically represents the estimated wage premia for each 5 th percentile of the earnings distribution. It shows a polarization of the wage differentials at the end points of the distribution for shift workers. Across the wage distribution, the differences in remunerations are rather U-shaped. Comparing wage differentials at the two extreme quantiles (0.95 and 0.05$)$ reveals a difference of 2 percentage points. Shift workers at the 5th percentile earn wage differentials of 9.1 percent. Between the 15th and the 55th quantile, wage differentials are very similar and steeply increase afterwards.

In comparison, wage differentials of men with unusual working schedules steadily increase by quantile. The difference between the extreme quantiles ( 0.95 and 0.05$)$ amounts to 13.7 percentage points. Wage differentials are rather stable up to the 40th percentile and increase steadily thereafter. At the upper part of the earnings distribution, net hourly wage compensations for work during unusual hours increase to levels up to 10 percent and reach even 16.9 percent for the 95th quantile.

\section{Conclusion and Discussion}

15 percent of the European and the German workforce worked shifts in the year 2001 and such jobs are typically dominated by men. The average rate of shift work was with 10 percent lowest in 
France, Denmark and the Netherlands and reached 20 percent in the Northern countries as well as in Belgium, Italy and Austria in 2001. With a progressing economic globalization, shift work and to a growing extent work during non-standard hours have become fundamental work patterns and are now integral parts of the lifestyle of a large part of a nation's population. The resulting expansion of world demand required countries to react by, for example, relaxing work time regulations and also by prolonging shop opening hours. As a consequence, the distribution of working hours across a standard workday widened and shift work as well as work at unusual hours gained more importance and will continue to do so in the future.

The higher risks to health induced by these jobs require firms to give workers monetary incentives as compensation to attract workers to accept such jobs despite these risks. This paper analyzes these monetary incentives for men who either choose to work shifts or during unusual working hours. Treatment effect models reveal a significant and negative selection of shift workers but none for men who work during non-standard hours. Wage premia amount to 9 - 10 percent. Separate estimations of hourly remunerations based on switching regressions with endogenous switching are not able to identify a significant negative selection into shift work or work at unusual hours. In contrast, daytime workers have large and positive unmeasured components which further increase their wages and which allow them to avoid work with undesired schedules. In addition, workers who devote more than 10 hours per day to market work tend to not be compensated financially for the associated work burden which are potentially outweighed by additional non-pecuniary aspects of the job such.

For a better understanding of the dynamics of wage differentials across the wage distribution, quantile regressions show a U-shaped impact across the earnings distribution. Hence, a polarization at the extreme points is revealed for shift workers. Wage differentials of men with unusual working hours, in contrast, tend to increase steadily by quantile. Accounting for the negative selection of shift workers would possibly intensify wage premia in particular for men at the upper part of the earnings distribution.

The significance of the selection term, its sign and magnitude further emphasize the importance of such working conditions for the German labor market. The combination of a sizeable wage differential, particularly at higher quantiles, and the high probability to work in such jobs among blue-collar and low-skilled workers suggests that such working conditions have a measurable impact on the overall distribution of wages. The fact that wage premia are highest at the upper end, might even entail a widening of the overall wage distribution. Since it is additionally workers in the 
lower half of the wage distribution that predominantly work in the early morning hours and thus contribute to a widening of the working hour distribution, the burden of such working schedules has hence to be disproportionately borne by already disadvantaged workers.

The sizeable wage differentials further imply higher opportunity costs for the respective workers which will further increase with a growing importance of such jobs. This will have however strong negative implications on the social life: higher opportunity costs of leisure further translate into a lower marginal utility of leisure and an increased difficulty to find suitable leisure companions which might in turn adversely affect well-being. These influences might mitigate the growth prospects expected from a widening of the working hours distribution (see also Jenkins and Osberg, 2005: Scheffel, 2011). 


\section{References}

Bøggild, Henrik and Anders Knutsson, "Shift Work, Risk Factors and Cardiovascular Disease," Scandivian Journal of Work, Environment and Health, 1999, 25 (2), pp. 85 - 99.

Burda, Michael C., Daniel S. Hamermesh, and Philippe Weil, "Total Work, Gender and Social Norms,” NBER Working Paper 13000, National Bureau of Economic Research, Inc 2007.

Costa, Giovanni, “The Impact of Shift and Night Work on Health," Applied Ergonomics, 1996, 27 (1), pp. $9-16$.

_ , "Shift Work and Occupational Medicine: An Overview," Occupational Medicine, 2003, 53 (2), pp. $83-88$.

Culpepper, Larry, “The Social and Economic Burden of Shift-Work Disorder," Supplement to The Journal of Family Practice, 2010, 59 (1), pp. S3 - S11.

Cunningham, J. Barton, "A Compressed Shift Schedule: Dealing with Some of the Problems of Shift-Work," Journal of Organizational Behavior, 1989, 10 (3), pp. 231 - 245.

Davis, Scott and Dana K. Mirick, "Circadian Disruption, Shift Work and the Risk of Cancer: A Summary of the Evidence and Studies in Seattle," Cancer Causes Control, 2006, 17, pp. $539-545$.

Duncan, Greg J. and Bertil Holmlund, "Was Adam Smith Right After All? Another Test of the Theory of Compensating Wage Differentials," Journal of Labour Economics, 1983, 1 (4), pp. 366 379.

Folkard, Simon and Philip Tucker, "Shift Work, Safety and Productivity," Occupational Medicine, 2003, 53 (2), pp. $95-101$.

Hamermesh, Daniel S., "Shirking or Productive Schmoozing: Wages and the Allocation of Time at Work," Industrial and Labor Relations Review, 1990, 43 (3, Special Issue: Do Cempensation Policies Matter?), pp. 121S - 133S.

_, Workdays, Workhours and Work Schedules: Evidence for the United States and Germany, Kalamazoo, MI: W.E. Upjohn Institute for Employment Research, 1996.

_ , "Changing Inequality in Markets for Workplace Amenities," Quarterly Journal of Economics, 1999, 114 (4), pp. 1085 - 1123. 
_ , "The Timing of Work over Time," Economic Journal, 1999, 109 (452), pp. 37 - 66.

Jenkins, Stephen P. and Lars Osberg, "Nobody to Play With? The Implications of Leisure Coordination," in Daniel S. Hamermesh and Gerard A. Pfann, eds., The Economics of Time Use, Elsevier, 2005, pp. $113-145$.

Kostiuk, Peter F., “Compensating Differentials for Shift Work,” The Journal of Political Economy, 1990, 98 (5), pp. $1054-1075$.

Lanfranchi, Joseph, Henry Ohlsson, and Ali Skalli, "Compensating Wage Differentials and Shift Work Preferences. Evidence from France," Working Papers in Economics 55, Göteborg University, Department of Economics 2001.

_ ,_, and _ , "Compensating Wage Differentials and Shift Work Preferences," Economics Letters, 2002, 74 (3), pp. $393-398$.

Maddala, Gangadharrao Soundalyarao, Limited Dependent and Qualitative Variables in Econometrics, Cambridge: Cambridge University Press, 1983.

Mayshar, Joram and Yoram Halevy, “Shiftwork," Journal of Labor Economics, 1997, 15 (1), pp. S198 $-\mathrm{S} 222$.

McNabb, Robert, "Compensating Wage Differentials: Some Evidence for Britain," Oxford Economic Papers, 1989, 41 (2), pp. 327 - 338.

Mellor, Earl F., “Shift Work and Flexitime: How Prevalent Are They?,” Monthly Labor Review, 1986, 109 (11), pp. $14-24$.

Minors, D. S., A. R. Scott, and J.M. Waterhouse, "Circadian Arrhythmia: Shiftwork, Travel and Health," Occupational Medicine, 1986, 36 (4), pp. 39 - 44.

Presser, Harriet B., "Shift Work and Child Care among Young Dual-Earner American Parents," Journal of Marriage and Family, 1988, 50 (1), pp. 133 - 148.

_ , "Job, Family and Gender: Determinants of Nonstandard Work Schedules Among Employed Americans in 1991," Demography, 1995, 32 (4), pp. 577 - 598.

Rosen, Sherwin, “The Theory of Equalizing Differences," in O. Ashenfelter and R. Layard, eds., Handbook of Labor Economics, Vol. 1, Elsevier Science Publishers BV, 1987, chapter 12. 
Scheffel, Juliane, “How do Unusual Working Schedules Affect Social Life?,” 2011. 2011.

Schumacher, Edward J. and Barry T. Hirsch, "Compensating Differentials and Unmeasured Ability in the Labor Market for Nurses: Why Do Hospitals Pay More?," Industrial and Labor Relations Review, 1997, 50 (4), pp. $557-579$.

Shiells, Martha, "Hours of Work and Shiftwork in the Early Industrial Labor Markets of Great Britain, the United States, and Japan," The Journal of Economic History, 1987, 47 (2), pp. 497 -499 .

Smith, Adam, The Wealth of Nations, New York: Modern Library Edition, 1776.

Statistisches Bundesamt, "Wo bleibt die Zeit? Die Zeitverwendung der Bevölkerung in Deutschland 2001/02," Technical Report, Statistisches Bundesamt, Wiesbaden, Germany 2003.

Tüchsen, Finn, Jeppe Jeppsen, and Els Bach, "Employment Status, Non-Daytime Work and Gastric Ulcer In Men," International Journal of Epidemiology, 1994, 23 (2), pp. 365 - 370.

White, Lynn and Bruce Keith, "The Effect of Shift Work on the Quality and Stability of Marital Relations," Journal of Marriage and Family, 1990, 52 (2), pp. 453 - 462. 


\section{SFB 649 Discussion Paper Series 2011}

For a complete list of Discussion Papers published by the SFB 649, please visit http://sfb649. wiwi.hu-berlin.de.

001 "Localising temperature risk" by Wolfgang Karl Härdle, Brenda López Cabrera, Ostap Okhrin and Weining Wang, January 2011.

002 "A Confidence Corridor for Sparse Longitudinal Data Curves" by Shuzhuan Zheng, Lijian Yang and Wolfgang Karl Härdle, January 2011.

003 "Mean Volatility Regressions" by Lu Lin, Feng Li, Lixing Zhu and Wolfgang Karl Härdle, J anuary 2011.

004 "A Confidence Corridor for Expectile Functions" by Esra Akdeniz Duran, Mengmeng Guo and Wolfgang Karl Härdle, J anuary 2011.

005 "Local Quantile Regression" by Wolfgang Karl Härdle, Vladimir Spokoiny and Weining Wang, January 2011.

006 "Sticky Information and Determinacy" by Alexander Meyer-Gohde, January 2011.

007 "Mean-Variance Cointegration and the Expectations Hypothesis" by Till Strohsal and Enzo Weber, February 2011.

008 "Monetary Policy, Trend Inflation and Inflation Persistence" by Fang Yao, February 2011.

009 "Exclusion in the All-Pay Auction: An Experimental Investigation" by Dietmar Fehr and Julia Schmid, February 2011.

010 "Unwillingness to Pay for Privacy: A Field Experiment" by Alastair R. Beresford, Dorothea Kübler and Sören Preibusch, February 2011.

011 "Human Capital Formation on Skill-Specific Labor Markets" by Runli Xie, February 2011.

012 "A strategic mediator who is biased into the same direction as the expert can improve information transmission" by Lydia Mechtenberg and J ohannes Münster, March 2011.

013 "Spatial Risk Premium on Weather Derivatives and Hedging Weather Exposure in Electricity" by Wolfgang Karl Härdle and Maria Osipenko, March 2011.

014 "Difference based Ridge and Liu type Estimators in Semiparametric Regression Models" by Esra Akdeniz Duran, Wolfgang Karl Härdle and Maria Osipenko, March 2011.

015 "Short-Term Herding of Institutional Traders: New Evidence from the German Stock Market" by Stephanie Kremer and Dieter Nautz, March 2011.

016 "Oracally Efficient Two-Step Estimation of Generalized Additive Model" by Rong Liu, Lijian Yang and Wolfgang Karl Härdle, March 2011.

017 "The Law of Attraction: Bilateral Search and Horizontal Heterogeneity" by Dirk Hofmann and Salmai Qari, March 2011.

018 "Can crop yield risk be globally diversified?" by Xiaoliang Liu, Wei Xu and Martin Odening, March 2011.

019 "What Drives the Relationship Between Inflation and Price Dispersion? Market Power vs. Price Rigidity" by Sascha Becker, March 2011.

020 "How Computational Statistics Became the Backbone of Modern Data Science" by James E. Gentle, Wolfgang Härdle and Yuichi Mori, May 2011.

021 "Customer Reactions in Out-of-Stock Situations - Do promotion-induced phantom positions alleviate the similarity substitution hypothesis?" by Jana Luisa Diels and Nicole Wiebach, May 2011.

\section{SFB 649, Ziegelstraße 13a, D-10117 Berlin http:/ / sfb649.wiwi.hu-berlin.de}

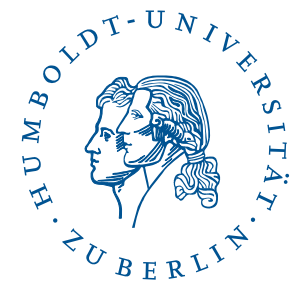




\section{SFB 649 Discussion Paper Series 2011}

For a complete list of Discussion Papers published by the SFB 649, please visit http://sfb649. wiwi.hu-berlin.de.

022 "Extreme value models in a conditional duration intensity framework" by Rodrigo Herrera and Bernhard Schipp, May 2011.

023 "Forecasting Corporate Distress in the Asian and Pacific Region" by Russ Moro, Wolfgang Härdle, Saeideh Aliakbari and Linda Hoffmann, May 2011.

024 "Identifying the Effect of Temporal Work Flexibility on Parental Time with Children" by Juliane Scheffel, May 2011.

025 "How do Unusual Working Schedules Affect Social Life?" by Juliane Scheffel, May 2011.

026 "Compensation of Unusual Working Schedules" by Juliane Scheffel, May 2011. 